\title{
鉄管内走行ロボットの開発
}

\author{
川口圭 史* 吉田乙雄* 車 谷 治 通* 菊田 隆*
}

\section{Development of an In-pipe Inspection Robot for Iron Pipes}

\author{
Yoshifumi Kawaguchi*, Itsuo Yoshida*, Harumichi Kurumatani* and Takashi Kikuta*
}

\begin{abstract}
This paper describes a new mechanism, communication system, and vision system of an in-pipe inspection robot. To date, inspection robots have had such limitations as mobility of the robot to turn in a T-shaped pipe or move in a plug valve. The new mechanism based on our dual magnetic wheels overcomes these limitations without difficulty in control. This dual mechanism, resembling a crawler, enables the robot to climb over sharp obstacles like sleeve and dresser joints. Another drawback of earlier robots is that the friction between the pipe and the cables for communication and power supply makes it difficult to move a long distance. A fiber-optic communication system can reduce friction. The spooler of the fiber- ${ }^{-}$optic communication cables and batteries are mounted on the robot and the cables are rolled and unrolled when the robot is going forward and backward, respectively. The new vision system has been significantly miniaturized, enabling it to clearly view and inspect the pipe welds underneath the robot while gazing ahead for navigation. The reflection of slit light made by a light-emitting diode and a cylindrical lens is used to diagnose the pipe weld.

An experimental inspection robot has been successfully made to confirm the efficiency of the new mechanism and the vision system.
\end{abstract}

Key Words: Vehicle in Pipe, Magnetic Wheels, Fiber-Optic Cable, Vision System, Inspection

\section{1. はじめに}

ガス導管に代表される地下埋設管の外面検査は地上にある管 と異なり掘削・埋め戻し作業を伴うため効率的に行うことがで きない. それはまず $1.2[\mathrm{~m}]$ 以上の深さに埋設されている検査 部分全体が露出するまで掘削し，検査終了後は検査前と同じ状 態に土を埋め戻す作業が必要なためである（路面沈下対策とし て添圧機で数回の締め固めも行う).さらに埋め戻し土は一定 の基準を満足させるため, 掘り起こした土砂は用いず埋め戻し 用の土砂（山砂・改良土）を用いる，これらの土砂を運搬する ためにはトラック等も必要になる．以上の作業は実際の検査以 上に時間・費用がかかる。

掘削作業の効率化に関しては地下埋設物探査 [1]により予め 地下の状態を把握し, 他埋設物を避けて目的の管まで高速に掘 削することが可能になりつつある.しかし，それだけでは掘削 効率のある程度の向上は望めても掘削時間の抜本的な削減は望 めない. そこで検査方法自体の見直しが重要になってくる．検

原稿受付 1995 年 2 月 6 日

*大阪ガス株式会社

*Osaka Gas Co., Ltd
査方法としては前述の外面検査以外に管内部から検査を行う内 面検査がある. 内面検査の掘削量は検査器挿入ピット分だけあ り，そのため掘削・埋め戻し作業は外面検査と比べて時間・費 用とも少ない．さらに掘削量の減少は工事に伴う埋設管上の道 路の占有時間・占有面積の減少となり, 歩行者・車の移動を妨 げないという公共的な利点も大きい．特に検査筒所に交通量の 多い道路・交差点が含まれる場合はそこを避けてピットを掘つ て検査できる.

現在内面検查として管内テレビカメラでの目視 $[2]$ は既に実 用化されている。 また内面からの外面腐食検査は渦流探傷法 [3]，リモートフィールド渦流法 [4] などが確立している.さ らにライブジョイントシール工法 $[5]$ と呼ばれる管の簡易修繥 方法や管内溶接ロボット $[6]$ も実用化されている. したがって 内管検查・修繥に関する技術はある程度整えられていると考え て良い.しかしこの内面検査にもまだ問題が残されている。 そ の 1 つとして挿入ピットから検査箇所まで管内を移動する装置 （ロボット）の性能不足が挙げられる．現在までに様々な管内走 行ロボットに関する機構が提案されており，その中でも実用化 レベルのものも幾つか見られる $[2][7] \sim[9]$. しかし直径 $150[\mathrm{~mm}]$ から $600[\mathrm{~mm}]$ の鉄管を対象とする実用機には次の問 
題点が残っている†.

（問題点 1）管に対する占有断面積が大きい

占有断面積が大きいためバルブ等の狭路の通過やプラグ弁等 の突起物の回避ができない.さらにレジューサーでつながれた 異径管（設定した管径以外）内の移動も難しい.

(問題点 2) 管の曲がりに沿った移動しかできない 現状の実用機では L 字管を走行する場合, 管の曲がりに応 じて自然にロボット自体が曲がる機構を採用している．このた めT字管を直進せずに曲がり込むことができない. T字管は 埋設管によく用いられるため大きな適用範囲の制約になる.

（問題点 3）移動距離が短い

ロボットが牽引するケーブルと管体の摩擦が移動距離延長に 大きな支障となる (現状のロボットでは $100[\mathrm{~m}]$ 程度が限界). 特に L 字管ではケーブルと管体との摩擦が大きくなるので L 字管の走行回数が増えると移動距離はさらに減少する.

これらの問題点は内面検査を適用範囲の狭いものにしてお り，これらの解決により内面検査技術を向上し外面検査量を減 らすことが望まれている。そこで本論文ではこのような問題点 を解決した管内走行ロボット $(150[\mathrm{~mm}] \sim 600[\mathrm{~mm}]$ 用鉄管) の 概念を構築し，試作機を開発したので報告する。

\section{2. 移動機構 (二重磁石車輪)}

前述の問題点を解決するような移動機構に関する検討 $[10]$ を 行う。まず費用効果からこのロボットは $500[\mathrm{~m}]$ 以上の区間を 1 日 (8 時間) で作業することが求められている.この場合作業 時間等を考慮すると移動時間は長くとも $3 \sim 4$ 時間であり移動 速度として $3 \sim 5[\mathrm{~m} / \mathrm{min}]$ が要求される. 現在研究の行われて いる尺取り虫型[11]や歩行型はこれを満たすのは難しい. また ガス流に乗った機構[12]ではガス流が十分でない場合に適用が できない上に適宜停止する必要のある作業への適用にも問題が ある.したがってここでは移動速度の速い車輪型の移動機構が 適当と判断した。ただし単純に車輪型 $[8]$ とすると垂直管内の 昇降に問題が残るのでバネ車輪 $[2][9]$ や磁石車輪を用いる必 要がある。 バネ車輪の場合管に対する占有断面積が大きく, 曲 がりに沿った移動になるため（問題点 1)（問題点 2）を解決す るのが難しい．これに対して磁石車輪の場合その性質から利用 範囲が鉄管に限定されるが，占有断面積が小さく(問題点 1) を 解決できる。 さらに Fig. 1 に示すような平面的な移動方法を 採用すると複雑な機構や複雑な制御を用いずに (問題点 2) を解 決し，L字管，T字管内での移動ができる，したがってここで は磁石車輪型の機構を採用する。しかし普通の磁石車輪では継 ぎ手などの段差部分での乗り越えが難しい. 即ち Fig. 2 に示 すような状態で車輪は管に 2 点で接触するため $\mathrm{A} ・ \mathrm{~B}$ 点で付着 力が働き，B点を支点とした乗り越え動作を $\mathrm{A}$ 点での付着力 が妨げる.

\footnotetext{
†ガス導管の場合ガスの供給を停止させるという問題が発生する，供給し たままのガス導管への挿入装置は既に類似の実用装置があり開発に大き な障害はない. しかしロボットの形状及びケーブル等の制約から埋設管 を切断しその区間のガスを不燃物 (窒素) と入れ換えている。また挿入で きたとしても占有断面積が大きいと管断面の急縮小・拡大によるガス供 給圧力の渦流損失を招き供給に影響を与える.これよりガス供給停止問 題のためには (問題点 1)（問題点 3 ）を解決させる必要があることがわか る.
}

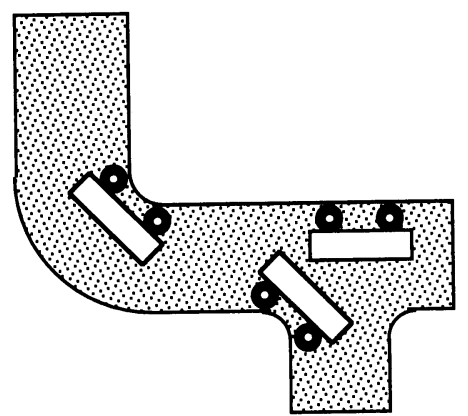

Fig. 1 Magnetic wheel robot

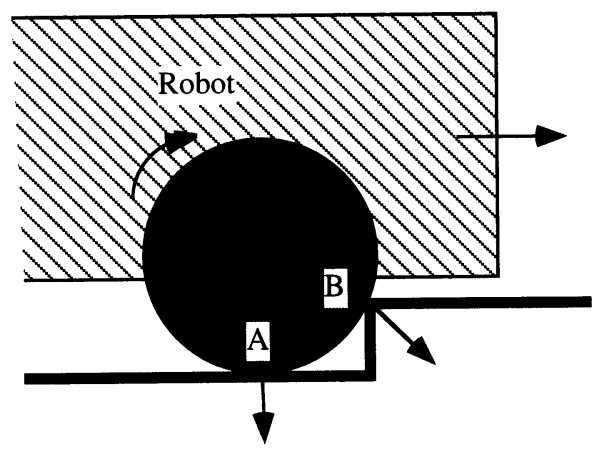

Fig. 2 Problem of magnetic wheel

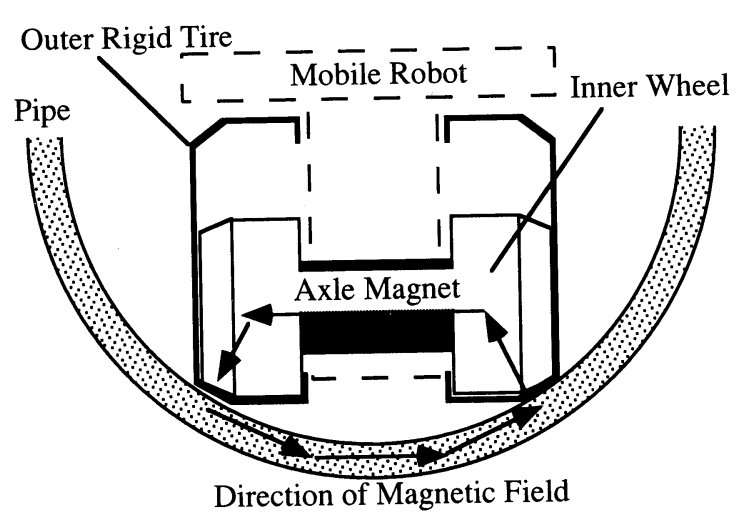

Fig. 3 Magnetic wheel concept

一般に段差走行に関してはクローラ型[13]が有効であるが車 輪の数が多くなると Fig. 1 に示す L 字管や T 字管内の走行に 支障をきたす。またクローラの車輪を小さくすると乗り越えら れる段差が小さいものになる。そこでクローラ型の原理を残し た二重磁石車輪を開発した．即ち Fig. 3 に示すように磁石を 車輪軸として用い磁性体の内輪及び外輪（剛体）を設ける（磁 石を内輪ではなく車輪軸にすることにより管体と閉磁路を生成 し強力な磁力を発生できる)。この二重磁石車輪によりロボッ トは Fig. 4 に示すように外輪の半径以下の段差を走行でき る.つまり Fig. 2 においてはB 点が支点となる乗り越えにな つたが Fig. 4 の 1 では支点とならずに内輪が外輪内を移動し ていく．そして 3 に示すようにB点が支点になった場合には 妨げる付着力が小さくなるため段差を乗り越えることができ 
Inner Magnetic Wheel

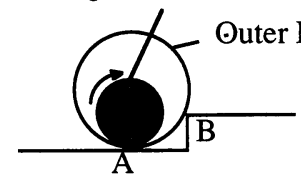

1. Outer Rigid Tire Stalls in a Sharp Obstacle

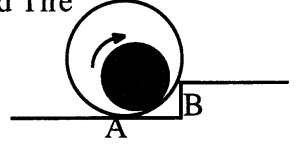

2. Inner Wheel Still Moves in the Sloping Bottom of Outer Rigid Tire

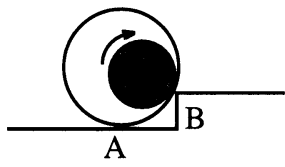

3. Inner Wheel Climbs inside Outer Rigid Tire

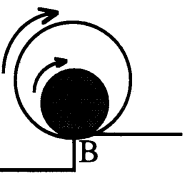

4. Outer Rigid Tire Climb a Sharp Obstacle

Fig. 4 Magnetic wheels climb a sharp obstacle

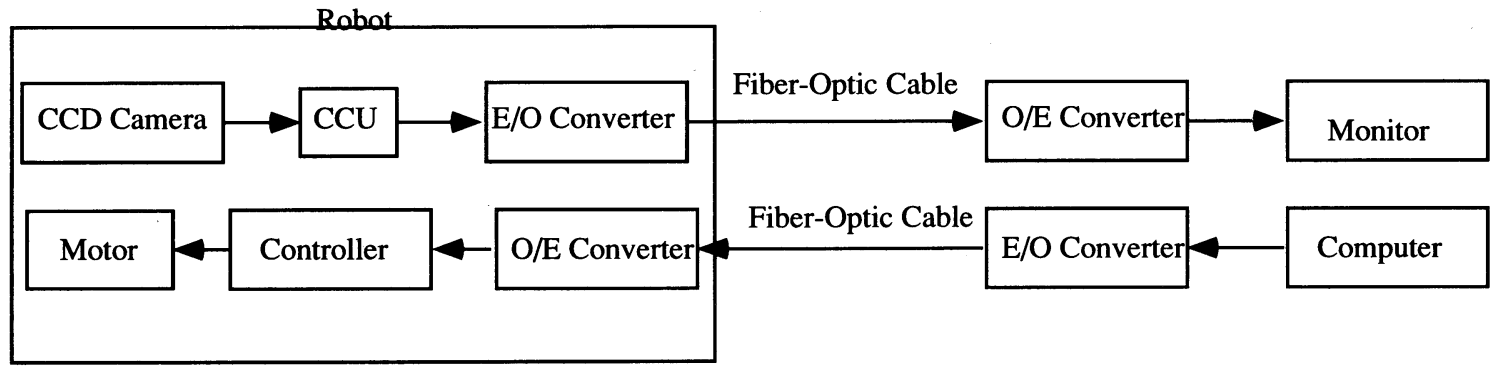

Fig. 5 Configuration of robot system

る.さらに二重であれば通常磁石車輪で問題になる錆付着も錆 が内輪から離れるときに除去しやすいという利点もある．以上 二重磁石車輪により（問題点 1)（問題点 2) を複雑な制御を行 わず解決することができる.

\section{3. 通信・制御ケーブルの検討}

次に（問題点 3）を解決するため通信・制御ケーブルの検討を 行う。理想的には電源・通信ケーブルをなくした自立走行ロボ ットであればよい. まずバッテリーを搭載することで電源ケー ブルの除去は可能である。しかし通信ケーブルの除去は直進用 ロボットでは可能[14]であるが無線通信の減衰が大きいため $\mathrm{T}$ 字管を含めた長距離での適用は難しい。逆に通信ケーブル を用いる場合でも移動距離の増大に伴い電圧降下の影響が大き くなり $500[\mathrm{~m}]$ の通信は難しい. そこでここでは信号の減衰の 小さい光ファイバーを用いる $(500[\mathrm{~m}]$ でファイバー巻き取り径 $20[\mathrm{~mm}]$ の場合，信号の減衰は $10 \%$ 以下)，この場合 Fig. 5 に 示すように制御信号は地上コンピュータから $\mathrm{E} / \mathrm{O}$ 変換器によ り光信号に変換され光ファイバーケーブルでロボットに送ら れ，ロボット内で $\mathrm{O} / \mathrm{E}$ 変換器により電気信号に戻される。ま た画像データや検査データはロボットに搭載してある $\mathrm{E} / \mathrm{O}$ 変 換器を介して光信号となり光ファイバーケーブル, 地上の $\mathrm{O} /$ $\mathrm{E}$ 変換器からモニターへと送られる。.さらに管体との摩擦を避 けるためにケーブルをローラーに巻きロボット側に搭載する. このローラーを前進時に巻きだし，後退時に巻き戻しすること により常にケーブルに張力のかからない状態, 即ちケーブルと 管体との摩擦のない状態，を維持できるので (問題点 3) を解決

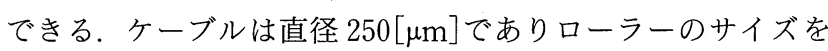
外径 $30[\mathrm{~mm}]$, 幅 $107[\mathrm{~mm}]$ とすると $500[\mathrm{~m}]$ 巻き付け後の外 径は $36[\mathrm{~mm}]$ となる.このローラーと $\mathrm{E} / \mathrm{O}$ 変換器, $\mathrm{O} / \mathrm{E}$ 変換 器, CCU (画像データがある場合), コントローラーはロボッ
トに搭載することがスペース的に可能である。これによると地 上設備はパソコンと $\mathrm{O} / \mathrm{E}$ 変換器, $\mathrm{E} / \mathrm{O}$ 変換器, モニターだけ になり運搬等が容易に行えるという利点もある.

\section{4. 溶接線検査システム}

内面検査の 1 つとしてカメラ検査（溶接線）がある.ここで はロボット搭載用溶接線検査システム開発について述べる [15].

まずロボットは走行時に約 $30[\mathrm{~cm}]$ 前方を観察する必要があ る（管内ロボットの前方環境認識の自動化に関する研究 [16]も 行われているがここではオペレーターによる判断に基づく). この前方観察用のカメラを溶接線検査へそのまま併用すること は検査精度から考えると不可能であり，上，下または横向きの 溶接線専用カメラが必要になる。しかしカメラを増設すること はスペースの問題上望ましくない. また 1 台のカメラで前方・ 側方と向きを変えることは可能であるが, 向きを変えるための 装置及び焦点を変更するための装置の追加を考えるとあまり効 果がない. そこでここでは 1 台のカメラで前方及び溶接線を同 時に観察できる装置を開発した。

具体的には Fig. 6 に示すようにカメラをまず下方向きに設 定する. カメラを前方としないのは導管の前方環境が比較的単 純であり詳細な情報を必要としないためである，また下向きに 設置するのは上方や側方では走行管径が違うと溶接線までの距 離が異なり焦点の調整が必要となるためである。そして $4[\mathrm{~cm}]$ 程度下方にある溶接線の状態を詳しく観察するために CCD カメラに接写リングを挿入し Fig. 7 のように画面を拡大 する (画面に縦 $30[\mathrm{~mm}] \times$ 横 $42[\mathrm{~mm}]$ が写る). 次にプリズムミ ラーを検出画像の一角に前方を映し出すようにカメラと溶接線 の間に設置した.この場合限られたスペース内での前方の焦点 の調整が重要になる．ここでは前方用のプリズムミラーの反射 
延長上に非球面レンズを設置することにより焦点の調整を行っ た.

また溶接線へはスリット光を照射し，その反射光のずれによ り状態を検知する，照射角度は斜め $\pi / 12$ であり，管に段差が あった場合，Fig. 7 に示すように反射光がずれる，そのずれを $d$ とすると段差 $x$ は

$$
x=k d / \tan (\pi / 12)
$$

と計算できる。ただし $k$ は管の状態により異なる変数であ る. 溶接線検査においては直管部分にロボットがいると考えて よいため $k$ は 1 と見なすことができる. Fig. 8 に段差におけ る検出画像を示す. 図から $d=6[\mathrm{~mm}]$ と測定され式(1)より段

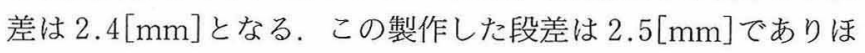
ぼ正確に測定できていることがわかる．このスリット光は発光 ダイオードをシリンドリカルレンズに通すことにより発生させ

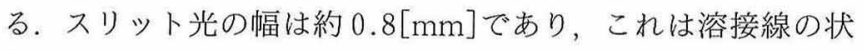
態を知るのに十分な細さである。 さらに全面照射用光源として 発光ダイオードを下方に 1 つ, 前方に 2 つ照射している.ここ で全て発光ダイオードを用いたのはバッテリーへの負担を軽減 するためである（消費電力：発光ダイオード 4 つ計 $0.4[W]$ ).

次に溶接線及び通常部分の検出画像を Fig. 9, Fig. 10, Fig. 11 に示す. Fig. 9 は溶接線上の走行であり溶接線の状態が観 察できる（管前方に写っているのは実験者の手である）. Fig.

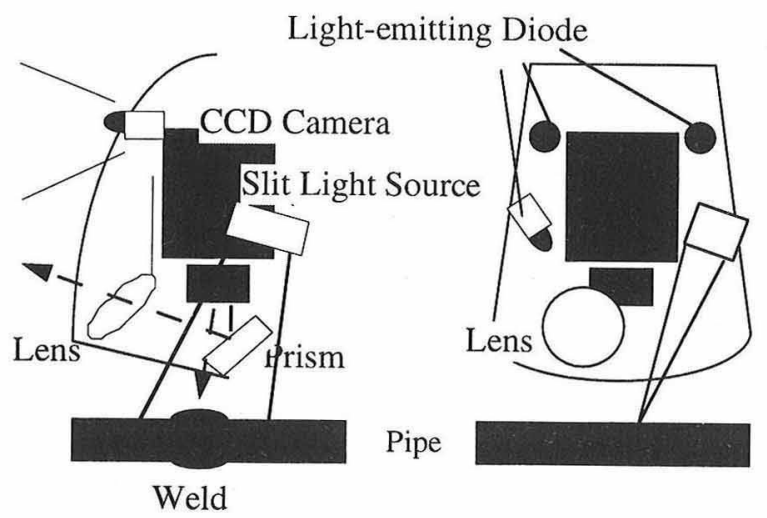

Fig. 6 Vision system

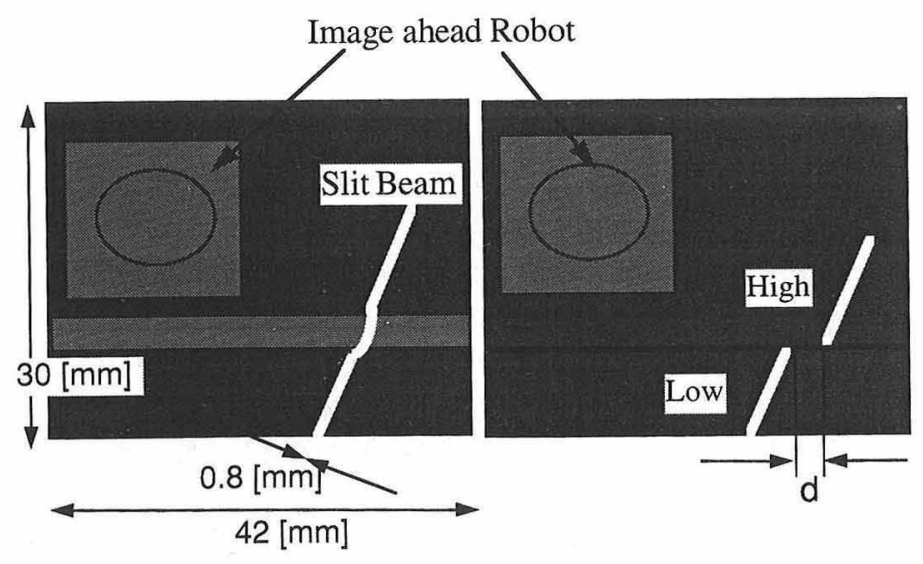

Fig. 7 Camera image

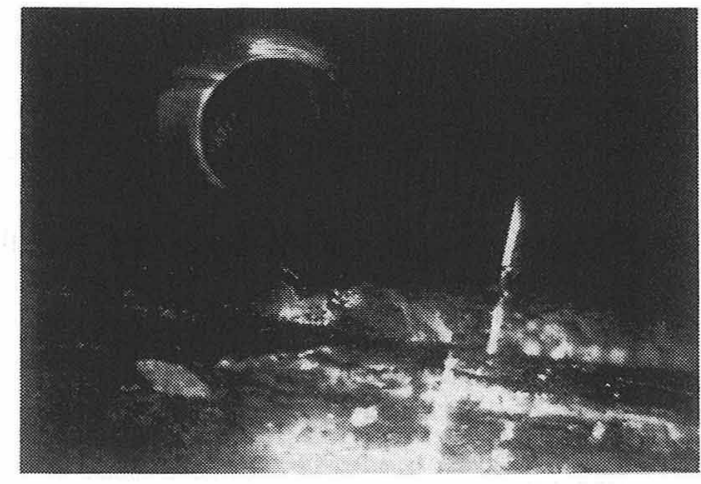

Fig. 8 Image of both forward and beneath the $\operatorname{robot}(1)$

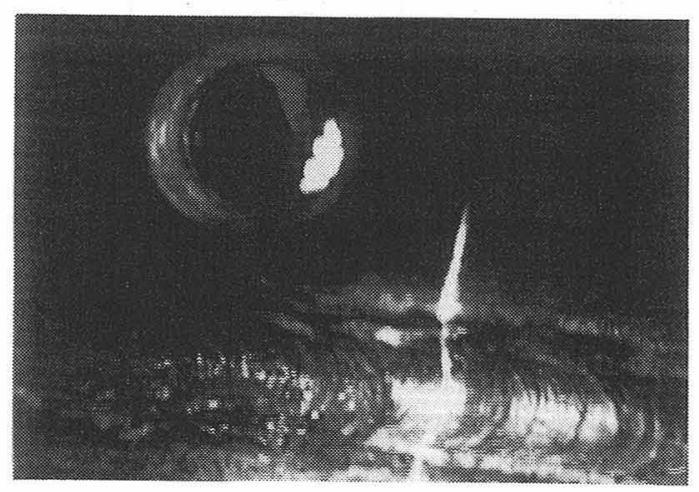

Fig. 9 Image of both forward and beneath the robot (2)

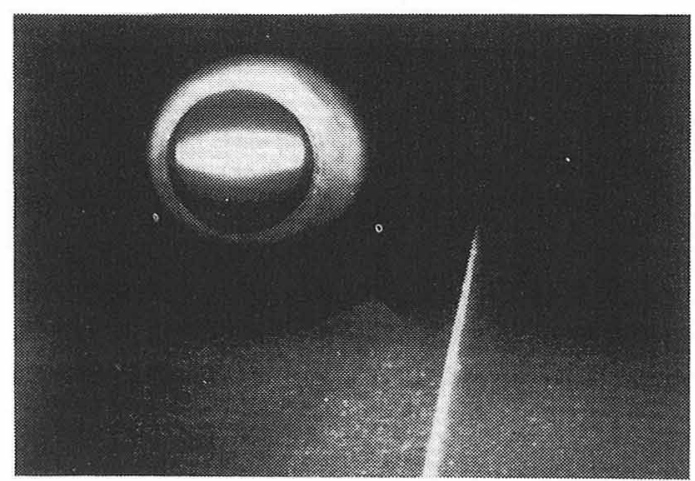

Fig. 10 Image of both forward and beneath the robot (3)

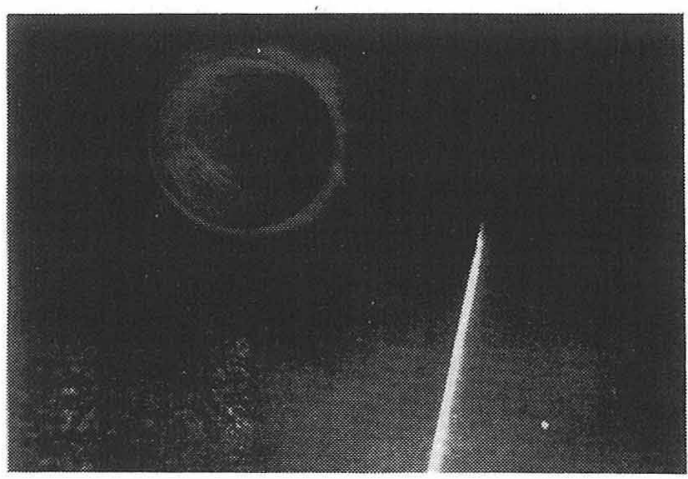

Fig. 11 Image of both forward and beneath the robot (4) 


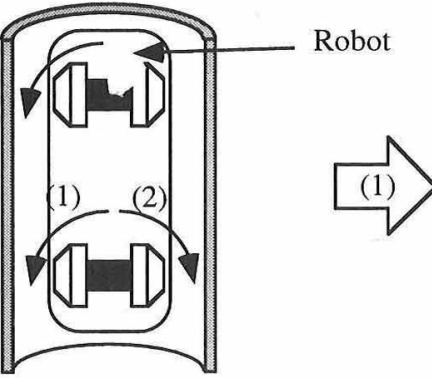

(a) Steering

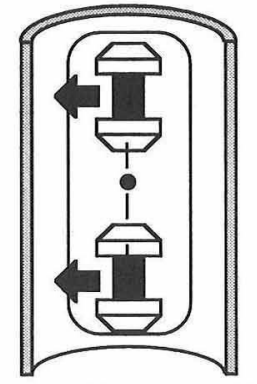

(b) Crabbing ( unstable )

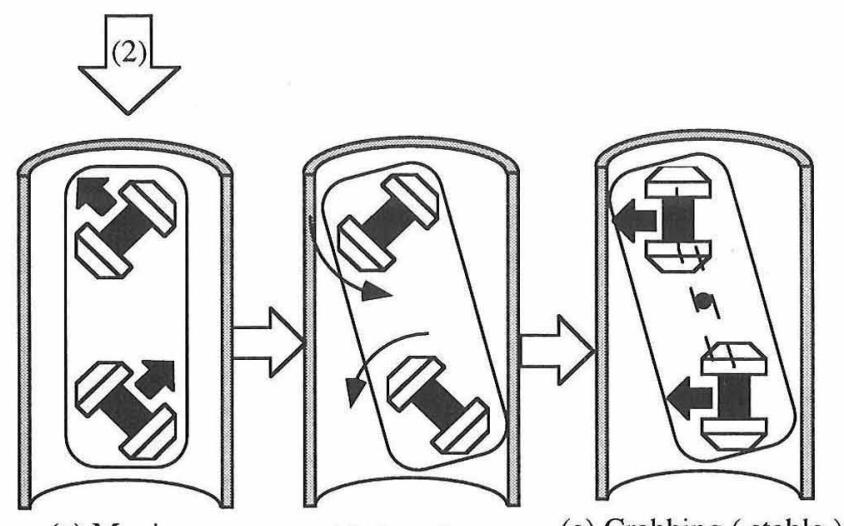

(c) Moving (d) Steering (e) Crabbing ( stable )

Fig. 12 Crabbing for inspection

10, Fig. 11 は溶接線以外の部分を走行している. Fig. 10 の前 方は T 字管 (管径 $150[\mathrm{~mm}]$ ) の突き当たり部分であり中心部に 横に広がった強い反射が見られる。また Fig. 11 では右曲がり の L 字管 (管径 $200[\mathrm{~mm}]$ ) であり左から右へ反射光が弱くなっ ているのがわかる．これらから操作者は全面照射の反射光の状 態から前方の管の形状を判断できることがわかる．なお実際の 検出画像も白黒である。こ机は発光ダイオードが赤色光であり カラー画像では逆に地上モニターで見にくいためである。

この検查装置では溶接線全周を検查するためにはロボット自 身が溶接線に沿って走行する必要がある。基本的にこれは Fig.12(a) から（b ）のようにロボットが $\pi / 2$ 車輪を回転させ ることによって可能になる（ロボットは駆動用以外に操舵用の モーターが必要になる)。しかしこの場合管に対して 4 つの車 輪の接地点が一直線上にのるため振動，加速度等の影響を受け て転倒する可能性が高い。そこで(c)に示す状態になるように $\pi / 2$ 以下に車輪を回転させ，その後で車体を斜化させ，（e）に 示す状態にすることによりさらに安定な円周方向走行方法が考 えられる，ただしこの場合には確実に車輪が管に対して平行に なっている（安定な吸着力を得る）ことが重要である。このた めには操舵角を検出するだけではなく吸着の程度を知りフィー ドバック制御を施す必要がある。

\section{5. 試作ロボット開発}

以上の移動機構・通信制御装置・小型視覚装置を搭載した口 ボットを試作した

ロボットはTable 1 に示すように全長 $410[\mathrm{~mm}]$, 幅

Table 1 Specifications of the Robot

\begin{tabular}{l|l}
\hline Size & $410 \times 90 \times 140[\mathrm{~mm}]$ \\
\hline Weight & $4.25[\mathrm{~kg}]$ \\
\hline Diameter of Wheel & $\begin{array}{l}59[\mathrm{~mm}] \cdots \text { Outer Rigid Tire } \\
46[\mathrm{~mm}] \cdots \text { Inner Wheel }\end{array}$ \\
\hline Clamping Force & $30 \sim 43[\mathrm{~kg} /$ wheel $]$ \\
\hline Motors & $\begin{array}{l}2 \text { for Drive, } 2 \text { for Steering } \\
1 \text { for Cable Roller }\end{array}$ \\
\hline Max. Speed & $5[\mathrm{~m} / \mathrm{min}]$ \\
\hline Max. Torque & $6.4[\mathrm{~kg}-\mathrm{cm}]$ \\
\hline Sensor & CCD Camera \\
\hline
\end{tabular}

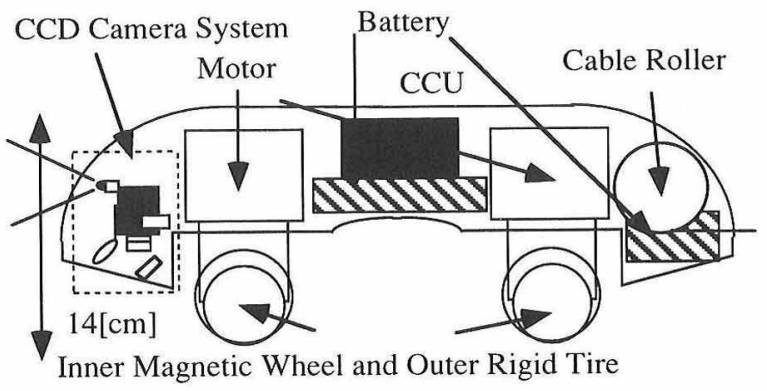

$41[\mathrm{~cm}]$

Fig. 13 Conceptual configuration of robot

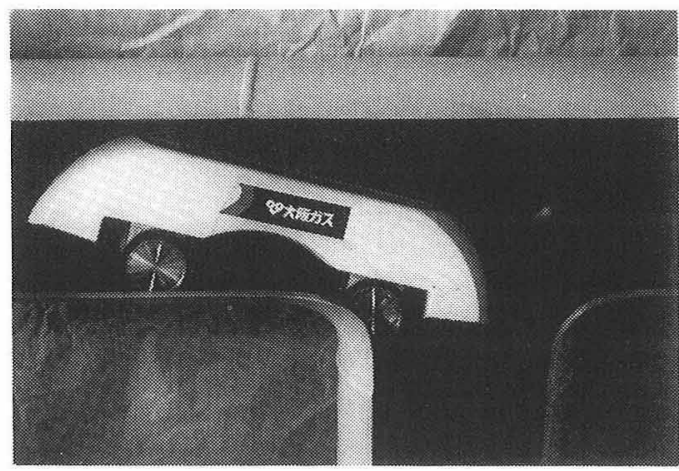

Fig. 14 Picture of pipe inspeciton robot

$90[\mathrm{~mm}]$, 高さ $140[\mathrm{~mm}]$ でありバルブなどの狭路の通過, プ ラグ弁の回避も行えるサイズである。形状は Fig. 13, Fig. 14 に示すように $150[\mathrm{~mm}]$ の L 字管走行ができるようにロボット の底の部分，前方及び後方の上部が削られている．また内輪，

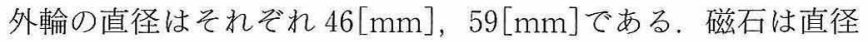
$31.75[\mathrm{~mm}]$, 高さ $44.0[\mathrm{~mm}]$ の円柱型ネオジム鉄製であり, 1 車軸で 30〜 43[kgf]程度の付着力 (外輪ありの状態)を有してい る.フレームの材質はアルミで本体カバーとしてプラスチック を用いて全体として $4.25[\mathrm{~kg}]$ と軽量化している.

バッテリーは $8.4[\mathrm{~V}] \times 1.5[\mathrm{~A}]$ (Normal), 16.8[V]X $3.0[\mathrm{~A}] （$ Turbo）の 2 通りのモードを前後輸の操舵・駆動モー 
管内マルチロボット デモプログラム

大阪ガス株式会社

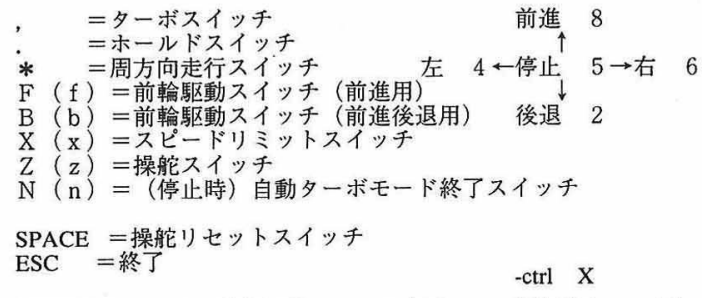

前輪操舵 $=0$ 後輪操舵 $=0(35)$ 制御指令 $=$

Fig. 15 Control monitor
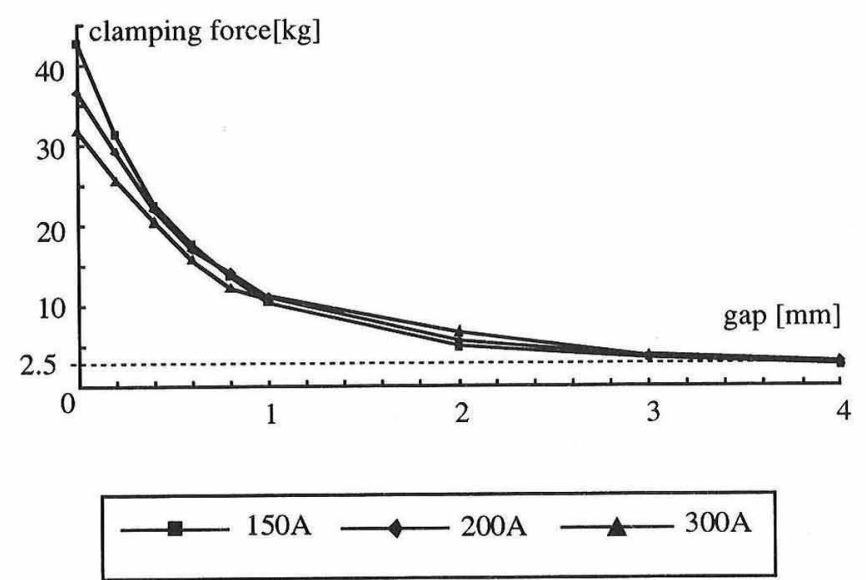

Fig. 16 Clamping force

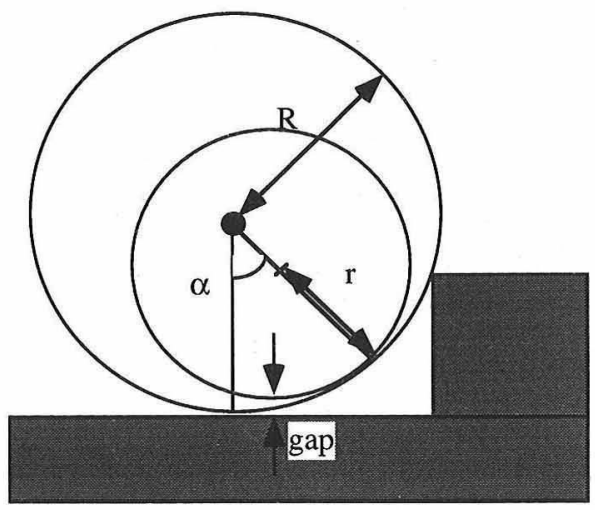

Fig. 17 Clamping force and gap

ターに供給することができる。それぞれのモードでの牽引力 (駆動前後輪和) は $1.8[\mathrm{kgf}] ， 5.1[\mathrm{kgf}]$ ，トルク (駆動一輪) は $2.3[\mathrm{~kg}-\mathrm{cm}], 6.4[\mathrm{~kg}-\mathrm{cm}]$, 最高速度は $3[\mathrm{~m} / \mathrm{min}], 5[\mathrm{~m} /$ $\min ]$ である。段差走行，垂直管走行などトルクが必要な場合 のみ Turbo を使用して効率的に走行できる，またケーブルロ ーラー用モーターには $16.8[\mathrm{~V}] \times 0.50[\mathrm{~A}]$ を供給できる.

基本的な制御はロボット搭載の制御回路で行うため外部コン ピュータからの指令は前後輪の速度, 角速度, 照明, Turbo/ Normal の切り替え, ローラーの巻取りなど 10 種類をパソコ
ン（IBM-PC 33[MHz]，NEC PC-98 Note 33[MHz] で実験） からパルスとして送信するだけである（Fig. 15 に操作 CRT の 出力を示す). 各パルスは $0.8 \sim 2.0[\mathrm{~ms}]$ の幅であり次の 10 種 類のパルスまでの間隔は $20[\mathrm{~ms}]$ 開いている.これは移動口ボ ットの制御指令としては十分実用的な短さである.

実際に直管， $\mathrm{T}$ 字管， L 字管，バルブ内通過実験を行い良好 な実験結果が得られた。また移動中のカメラ画像は振動の影響 もなくモーターからのノイズも見られなかった：このことから 本移動機構が管内移動に有効な手段であることが判断できる.

錆などで磁石車輪と鉄管の間にギャップが存在する場合には 付着力の減少が予想される，そこでギャップと付着力の関係に ついての実験結果（1 車輪軸あたり・車輪軸 $700[\mathrm{~g}]$ は含まず） について Fig. 16 に示す。それぞれのグラフは管径が $150[\mathrm{~mm}], 200[\mathrm{~mm}], 300[\mathrm{~mm}]$ の場合である.これよりギャ ップ $1[\mathrm{~mm}]$ があった場合でも付着力 10 [ $\mathrm{kg} /$ 車輪 $], 4[\mathrm{~mm}]$ が あった場合でも付着力 $2.5[\mathrm{~kg} /$ 車輪 $]$ が得られることがわか る.

この付着力は天井走行が十分可能であるだけでなく垂直管昇 降等において何らかの理由で前輪（又は後輪）がはずれた場合 にも転落しないことを保証する。ここで付着力が管径により異 なるのは外輪と管体の接触状態が異なるためである.

段差部分においては Fig. 17 に示すように内輪, 外輪の半径 をそれぞれ $r, R$ とし，外輪が停止している際に内輪のみが走 行していく角度を $\alpha$ とする。このとき内輪と管との距離 $g$ は

$$
g=(R-r)(1-\cos \alpha)
$$

となる. いま $r=46[\mathrm{~mm}], R=59[\mathrm{~mm}]$ であり $\alpha=\pi / 4$ の場合 でもこの距離は約 $3.89[\mathrm{~mm}]$ となるため段差乗り越えでも自重 を支えるのには十分な值である．ただし（外輪の約半分の） 29.5[mm]程度の段差は乗り越えることができるはずであった が実験では $9[\mathrm{~mm}]$ (両輪)，14[mm（前輪のみ）となった.こ れはモーターが減速ギアを含めた搭載スペース・消費電力など により制約されており, 磁石車輪の磁力に比べて不十分であっ たためと考えられる.今後はモーターの高性能化・付着力の見 直しが必要になる．さらに前後輪の速度差を調整することによ つて性能向上も考えられるためこれについても検討を行う.

\section{6. ま と め}

本論文では従来の管内ロボットの問題点を解決した二重磁石 車輪型ロボットを提案し実機を試作した。これにより本ロボッ トが管内走行に有効な手段であることが示せた．また溶接線検 査システムがロボット搭載に際しても十分適用できることが示 せた．ただし耐久性を含めたシステム設計という観点から今後 のさらなる検討が必要である. 特に 2 章で示したように二重磁 石車輪は通常の磁石車輪と比べて錆などの影響は小さいが長距 離走行に伴い錆が累積したり，回避しきれずに管内の鉄片が付 着した場合には走行に支障をきたす可能性がある。そこでそれ を積極的に剥離するような機構も今後検討する必要がある.

本試作機においてはその機構の有効性を確認することを主目 的としたため移動距離・姿勢・付着力を知るためのエンコーダ ー・ジャイロ・傾斜計などのセンサーを設置するまで及ばなか った，特に付着力の測定は非常に難しく搭載可能なセンサーを 
提案することができなかった．このため周方向走行については 本論文では方法の提案だけに留まっている. 安定な周方向走行 を実現するためには適切なセンサー情報に基づくフィードバッ ク制御が必要であり今後の重要な課題である。

本試作ロボットにおいてはバッテリーに関して十分なスペー スを確保することができず 30 分程度の実働時間しか得ること ができなかった．これに関しては電池の高性能化・搭載スペー スの確保が重要になる. 特に搭載スペースに関連しては多両連 結も検討する必要がある，またケーブルの巻き取り巻き戻しは ケーブルの残量によって変化させる必要があり, その制御に関 しても今後検討する必要がある. さらに認識・検査・制御の自 動化も本ロボットの重要な課題である.

\section{参 考 文 献}

[1] 北村, 中山, 川中, 高木：“2 次元 FFT 処理によるレーダーロケーター 探査画像の画質改善”, 第 24 回画像工学カンファレンス, pp. 179-182, 1993.

[2] 岡島, 中村, 未沢, 城, 藤原, 金原, 池田, 白石, 岡田 : “鋼管溶接部検查 用管内 TV カメラの開発”, ロボティクス・メカトロニクス講演会, pp. 655-660, 1994.

[ 3 ] 平岡, 坂本: “渦流探傷法によるガス導管の診断について”, 非破䘫検 査, 35 (2 A), pp. 156/157, 1986.

[4] 菊田: “鋼管検查用リモートフィールド渦流法のモデル化”, 非破壞検 查, no. 40, pp. 658-665, 1991.
[5] 尾上, 松井, 秋田, 細野, 佐藤, 大日向：“ライブジョイントシール工法 の開発”, 配管技術, vol. 36, no. 8, pp. 133-140, 1994.

[6] 中村, 黑田, 堤之, 矢野: “既設鋼管溶接部の補修用内面溶接ロボット (特殊環境下におけるロボット技術)”, MOTION ENGINEERING JAPAN'94 シンポジウム, D 6-1-1/D 6-1-8, 1994.

[ 7 ] 佐藤：“実用ロボット技術に必要なもの一壁面ロボット，管内ロボッ トを例に一”, 日本ロボット学会誌, vol. 12, no. 8, pp. 1132-1136, 1994.

[8 ] 仕入, 石川, 瀧口, 水野, 津坂 : “大口径管内堆積物回収ロボットの開 発一第 1 報: 機構一”, 第 11 回日本ロボット学会学術講演会, pp. 1013-1014, 1993.

[9] 小堀, 藤田: “小口径ガス導管検査ロボット”, 第 2 回ロボットシンポ ジウム, pp. 193-198, 1992.

[10] 吉田, 車谷, 川口, 菊田： “導管内走行ロボット一移動機構に関する提 案一”, 第 4 回ロボットシンポジウム, pp. 239-244, 1994.

[11] 広瀬, 三井：“Whole Stem Drive 型配管内移動機構（螺旋回転型と しゃくとり虫型の提案”, 第 11 回日本ロボット学会学術講演会, pp. 1111-1114, 1993.

[12] Y. Okajima: "Automatic Inspection Robot Surveying Pipeline for Loss of Wall Thickness," 1995 International Gas Research Conference, vol. III, pp. 343-351, 1995.

[13] 内藤, 佐藤, 藤井 : “負荷分散クローラ機構の開発” , 日本ロボット学 会誌, vol. 5, no. 5, pp. 335-338, 1987.

[14] 陶山, 細原：“インテリジェント検査ロボットの開発”, 第 12 回日本口 ボット学会学術講演会, pp. 445-446, 1994.

[15] 川口, 吉田, 車谷, 菊田：“導管内走行ロボット一視覚装置の開発一”, 第 12 回日本ロボット学会学術講演会, pp. 447-448, 1994.

[16]川口, 坪内, 山田, 菊田, 有本：“自己組織化データベースを用いたガ ス導管環境認識”, 第 2 回ロボットシンポジウム, pp. 181-186, 1992.

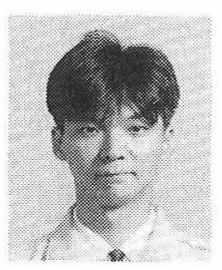

川口圭史（Yoshifumi Kawaguchi）

1964 年 4 月 7 日生. 1989 年神戸大学大学院修士課 程修了. 同年より大阪ガス(株)基盤研究所に勤 務. 1992 年〜1993 年オハイオ州立大学客員研究 員. 現在導管内走行ロボットの開発に従事.

(日本ロボット学会正会員)

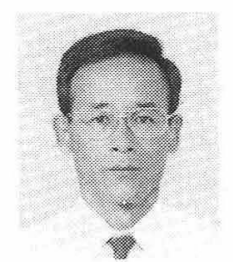

車谷治通 (Harumichi Kurumatani)

1948 年 9 月 23 日生. 1974 年, 岡山大学卒業. 同 年より大阪ガス (株) 供給部に勤務. 現在導管維持 管理技術の開発に従事.

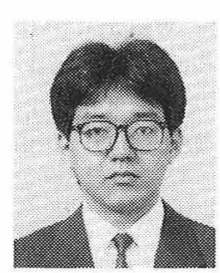

吉田乙雄 (Itsuo Yoshida)

1966 年 7 月 5 日生. 1992 年, 京都大学大学院修士 課程修了．同年より大阪ガス(株)供給部供給技術 センターに勤務. 現在導管内走行ロボットの開発 に従事.

（日本ロボット学会正会員）

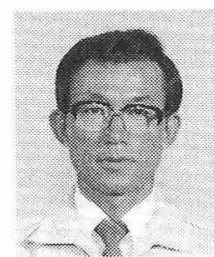

菊田 隆 (Takashi Kikuta)

1948 年 2 月 8 日生. 1972 年, 名古屋大学大学院修 士課程修了. 同年より大阪ガス(株) 開発研究所に 勤務. 現在導管内走行ロボットの開発に従事.工 学博士. 日本非破壊検査協会などの会員.

（日本ロボット学会正会員） 